\title{
ETIKA TEKNOLOGI VS ETIKA KRISTEN : “SEBUAH LOMPATAN IMAN DAN PENANTANG KE-EKSISAN IMAN KRISTEN DI ERA POST-TRUTH"
}

\author{
Evilina Thea Polnaya* \\ *Penulis adalah Mahasiswi Sekolah Tinggi Theologia Ebenhaezer, Tanjung Enim. \\ *Email: evi_polnaya@yahoo.co.id
}

\begin{abstract}
Abstrak:
Iman kepada Tuhan Yesus menjadi sebuah prioritas bagi orang percaya. Namun tidak bisa dipungkiri bahwa teknologi dapat merenggut keeksisan iman Kristen. Apalagi saat ini, kita dan semua orang percaya hidup di era post truth, dimana kebenaran sudah mulai dikaburkan dan diganti dengan sesuatu yang dilandasi dengan rasio manusia. Teknologi mendapat sebuah tempat yang paling penting dan meninggalkan ke-eksisan iman Kristen itu sendiri. Akibatnya, banyak orang percaya yang mulai membalikkan jalannya dari hal-hal yang rohani kepada sesuatu yang lebih menggiurkan dengan kecanggihan teknologi. Ke-4 tiang Rohani Yayasan Pelayanan Pekabaran Injil Indonesia yaitu Iman, Kesucian, Pengorbanan, dan Persekutuan dapat menjadi landasan yang teguh bagi orang- orang Kristen untuk dapat melompati iman dan mengalahkan ke-eksisan teknologi di era post truth.
\end{abstract}

\section{Pendahuluan:}

Diera post truth ini teknologi sangatlah dibutuhkan, teknologi menjadi sebuah prioritas. Setiap aktifitas rata-rata menggunakan teknologi. Manusia mulai menikmati keinstanan yang ditawarkan oleh dunia, meningkatkan intensitas komunikasi, sebagai media pertukaran data, memudahkan perolehan informasi, sarana bertransaksi dalam dunia bisnis. Manusia tinggal duduk diam, menggunakan kecanggihan teknologi dan semuanya akan beres. 
Saat ini kita hidup dizaman post-truth, masa dimana bukan fakta dan kebenaran yang penting, tetapi adalah emosionalitas informasi, dan reproduksinya secara berulang-ulang melalui media sosial. Kita hidup dizaman ketika "fakta-fakta alternative" menggantikan faktafakta actual, dan perasaan dianggap lebih penting daripada bukti. "Facts are futile", fakta adalah sia-sia. Penyebaran informasi dengan intensitas luar biasa ada sehingga seolah-olah ketidakpedulian terhadap kebenaran telah menjadi norma. Dan kita bahagia dengan ketidakbenaran itu. ${ }^{1}$

Diatas semuanya itu, ada banyak tantangan yang dapat kita jumpai dari kecanggihan teknologi ini. Dibalik banyaknya manfaat positif, tersimpan segudang intipan negative yang membuat manusia khususnya orang percaya untuk jatuh kedalam dosa yaitu membuat orang kecanduan, menambah ide kejahatan, peningkatan jumlah pengangguran, kualitas SDM menurun, dan masih banyak lagi bahkan teknologi banyak menyeret orang-orang percaya untuk jauh dari Tuhan. Inilah yang menjadi sebuah lompatan iman dan penantang ke eksisan iman Kristen.

\section{Metode Penelitian:}

Metode penelitian yang digunakan dalam tulisan ini adalah metode kualitatif studi perpus. Penulis mengumpulkan data dari berbagai sumber literature yang kemudian dianalisis secara objektif dan disimpulkan dalam bentuk deskriptif. Adapun sumber data dalam penelitian ini ada Alkitab, buku, jurnal, serta literature lain yang didapatkan dari internet.

\footnotetext{
${ }^{1}$ Moh Yasir Alimi, Mediatisasi Agama Post-Truth dan Ketahanan Nasional (Yogyakarta: LK.Is, 2019) 61
} 


\section{Pembahasan:}

\section{Teknologi Dalam Pandangan Iman Kristen}

Teknologi secara umum berarti suatu kecakapan dan kemampuan manusia untuk menguasi asek-aspek kehdupan. Menurut iman Kristen, teknologi adalah suatu segi yang sangat berharga dalam kehidupan manusia. Karena teknologi dapat digunakan manusia untuk melawan kelaparan, kemiskinan, penderitaan, dan wabah penyakit. Namun disisi lain teknologi menjadi alat bagi dosa untuk merajalela melalui tanggungjawab moral dalam menggunakan teknologi yang tidak sesuai dengan iman Kristen. ${ }^{2}$

Teknologi mesti disyukuri sebagai berkat Tuhan terhadap umat manusia. Teknologi merupakan peluang untuk mewujudkan secara maksimal keselamatan yang telah dinyatakanNya di dalam Kristus. Allah menghendaki manusia hidup sejahtera, teknologi memberi manusia rasa optimis terhadap kehidupan yang lebih baik. Teknologi merupakan jaringan kehidupan yang meliputi seluruh dunia dan semua aspek kehidupan. Didalam teknologi tersaji berkat Allah bagi umat manusia. ${ }^{3}$

\section{Teknologi VS Ke-4 Tiang Rohani Yayasan Pelayanan Pekabaran Injil Indonesia}

\section{Teknologi VS Iman}

Pengertian iman dalam Perjanjian Lama dijelaskan oleh Harun Hadiwidjono sebagai berikut: Di dalam Perjanjian Lama, kata iman berasal dari kata kerja 'aman' yang berarti 'memegang teguh'... umpamanya dalam arti memegang teguh pada janji seseorang, karena janji itu dianggap teguh atau kuat, sehingga dapat dipercaya. Jika diterapkan kepada Tuhan Allah, maka kata iman berarti, bahwa Allah harus dianggap sebagai Yang Teguh atau Yang Kuat

\footnotetext{
2 Jakop Hutapea, Etika Lingkungan (Malang: UMM, 2019) 18

${ }^{3}$ Einar M. Sitompul , Gereja Menyikapi Perubahan (Jakarta: BPK. Gunung Mulia, 2004) 101
} 
Menurut Perjanjian Lama, beriman kepada Allah berarti mengamini, bukan hanya dengan akalnya melainkan juga dengan segenap kepribadian dan cara hidupnya, kepada segala janji Allah yang telah diberikan dengan perantaraan Firman dan Karya-Nya. Perjanjian Baru, iman berarti: mengamini dengan segenap kepribadian dan cara hidupnya kepada janji Allah, bahwa Ia di dalam Kristus telah mendamaikan orang berdosa dengan diri-Nya sendiri, sehingga segenap hidup orang beriman dikuasai oleh keyakinan yang demikian . Penjelasan di atas menunjukkan bahwa iman yang dimaksud adalah iman yang disertai dengan perbuatan nyata dalam kehidupan sehari-hari. Orang yang menyatakan bahwa ia beriman pada Allah, harus membuktikan imannya itu di dalam kehidupannya. ${ }^{4}$

Teknologi dan iman Kristen bisa jadi sahabat yang erat jika digunakan dengan bijaksana. Dengan teknologi, kita dapat lebih memahami iman kita kepada Tuhan melalui blog-blog atau konten-konten rohani seperti bacaan-bacaan rohani, lagu-lagu rohani, dan filmfilm rohani. Namun saat ini, teknologi sudah banyak disalahgunakan.. Banyak ajaran sesat seperti pembela Lesbian, Gay, Bisexual dan Transgender menjadikan media sosial sebagai wahana kampanye pemikiran dan perilaku menyimpang. Semakin banyaknya sarana chatting yang dijadikan ruang untuk saling mengetahui dan mengenal antar sesama. ${ }^{5}$

Disinilah teknologi menjadi sebuah lompatan iman bagi orang percaya bahkan mengaburkan ke-eksisan iman Kristen. Kemunculan media sosial memperluas ruang lingkup post-truth. Post-truth adalah gejala yang bukan cuma menyoal urusan politik, tetapi juga telah masuk ke ranah sosial. Hoaks semakin mudah disebarkan dan diyakini masyarakat sebagai kebenaran. Masalah yang terjadi ialah bahwa sebagian dari orang Kristen khususnya kaum milenial meyalahgunakan kecanggihan teknologi dengan hal-hal yang negative, hidup mereka cenderung menginginkan sesuatu yang instan, melupakan proses dan malas berpikir dalam, apa lagi yang menyangkut filosofis. Generasi ini juga terkenal tidak loyal. Dari sisi pemikiran,

\footnotetext{
${ }^{4}$ Harun Hadiwijono, Iman Kristen (Jakarta: BPK Gunung Mulia, n.d.)17

${ }^{5}$ Mohamad Fadhilah Zein, Panduan Menggunakan Media Sosial Untuk Generasi Emas Milenial, 54
} 
generasi Milenial tergolong ampang dan kopong dari sisi pengetahuan. Bisa jadi ajaran-ajaran sesat ini merasuki pikiran orang-orang percaya. ${ }^{6}$

\section{Teknologi VS Kekudusan}

Kekudusan adalah salah satu dari sifat utama Tuhan yang menjadi ciri khasNya. Kekudusan adalah kasih yang sempurna, sehingga kekudusan dan kasih adalah sesuatu yang tidak terpisahkan, sebab Tuhan adalah Kudus (Im 19:2, Lk 1: 49, 1Ptr 1:15) dan Kasih (1Yoh 4: 10,16)

Dari pihak manusia, kekudusan (kesucian) berarti tanggapan atas karya Allah itu, terutama dengan sikap iman dan pengharapan. Kesucian merupakan sikap yang dinyatakan dalam hidup sehari-hari. Kekudusan itu terungkap dengan aneka cara pada setiap orang. Kekudusan merupakan atribut yang sangat penting untuk menjadi seorang Kristen yang kuat. Allah mengkehendaki agar kita menjadi istimewa dan disisihkan untuk umat-Nya.

Sekarang ini banyak orang tidak menyukai topik tentang kekudusan karena sebagian besar dari kita telah jatuh kedalam kekurangan standar Alkitab. Aturan kekudusan adalah sebuah istilah yang mengacu kepada serangkaian perintah yang diberikan didalam Kitab Imamat pasal 17 hingga $26 .^{7}$

Perlu kita ketahui bahwa masa remaja adalah masa di mana seseorang membuat kenangan dan antisipasi tentang masa depan. Suatu masa dimana seorang individu mencari identitas yang khusus. ${ }^{8}$ Anni Dyck dalam bukunya berjudul Tantangan dan Kebutuhan Remaja menuliskan "the fundamental task of adolescence is ego identity or self definition" artinya

\footnotetext{
${ }^{6}$ Arum Faiza, Sabila J Firda, dkk, Arus Metamorfosa Milenial, 8-9

${ }^{7}$ Dag Heward Mills, Bagaimana Menjadi Orang Kristen Yang Kuat, (Parchment House, 2015) 6

${ }^{8}$ Daniel Nuhamara, PAK Remaja, (Bandung: Jurnal Info Media, 2008), 10-11
} 
penting dalam masa remaja adalah menemukan diri sendiri, sehingga pada akhir masa remaja itu ia dapat mengatakan dengan yakin itulah aku. ${ }^{9}$

Sudah banyak sekali penulis perhatikan karna kemajuan teknologi media massa, terdapatnya aplikasi-aplikasi terbaru seperti Live Bigo, VCx, gambar diam, film, dan masih banyak yang lain yang mempertontonkan video wanita berpakain sexi/pornografi. Disini kita dapat melihat bahwa teknologi menjadi sebuah lompatan iman yang menghambat ke-eksisan iman Kristen apalagi di era post truth ini.

\section{Teknologi VS Pengorbanan}

Semangat rela berkorban biasanya akan tumbuh didalam diri kita masing-masing ketika dengan sungguh-sungguh kita menanamkan semangat itu sejak kecil. Rela berkorban tidak menuntut kehidupan yang sarat aturan atau berpantang kesenangan. Ini tidak membutuhkan penyangkalan diri secara ekstrem yang merampas sukacita atau kepuasan kita. Rela berkorban semata-mata berarti "mengorbankan kepentingan, kebahagiaan, serta keinginan, demi tugas atau kesejahteraan orang lain". Yesus Kristus adalah teladan utama dalam memperlihatkan semangat rela berkorban. Dalam keberadaannya sebagai manusia saat berada di muka bumi ini, Ia memiliki hubungan yang akrab dan intim dengan Bapa-Nya termasuk dengan umat manusia yang selalu diarahkannya ke jalan terbaik.

Indonesia adalah "raksasa teknologi digital Asia yang sedang tertidur". Jumlah penduduk Indonesia yang mencapai 250 juta jiwa adalah pasar yang besar. Pengguna smartphone Indonesia juga bertumbuh dengan pesat. Lembaga riset digital marketing Emarketer memperkirakan pada 2018 jumlah pengguna aktif smartphone di Indonesia lebih dari 100 juta orang.

Pertanyaan bagi kita adalah, apa yang telah kita korbankan dalam kehidupan ini bagi Tuhan? Bahkan kalau dihitung-hitung, lebih banyak uang yang kita gunakan untuk membeli kuota internet dari pada memberikan persembahan, lebih banyak waktu yang kita gunakan

\footnotetext{
${ }^{9}$ Anni Dyck, Tantangan dan Kebutuhan Remaja, (Batu-Malang: YPPII, 1982), 9-10
} 
untuk teknologi daripada merenungkan firman Tuhan, lebih banyak ke-eksisan yang dipaparkan di media sosial dari pada ke eksisan dalam pelayanan di gereja.

\section{Teknologi VS Persekutuan}

Persekutuan menggambarkan sesuatu yang bersifat subjektif, pengalaman akan kehangatan dan keamanan karena kehadiran orang lain. Persekutuan yang otentik adalah persekutuan yang menjadi saksi bahwa kita berbagi bersama dalam rahmat Allah Bapa, Putra dan Roh Kudus. ${ }^{10}$

Saat ini kita sedang menikmati suatu fenomena ketika masyarakat menggeser aktivitasaktifitas yang awalnya dilakukan didunia nyata, ke dunia maya. Aktifitas fisik tidak lagi bertumpu pada interaksi tatap muka melainkan menjelma interaksi daring (online). Hubunganhubungan sosial diambil alih oleh media teknologi informasi.

Media sosial yang menginsisiasi lahirnya model interaksi baru yang lebih inofativ dan masiv, tidak diragukan lagi telah mendorong terciptanya pola perilaku sosial baru dalam kehidupan umat beragama. Perubahan drastic dianah ini adalah teknologi mengartikulasikan agama dalam dunia kehidupan semakin distributive atau depersonalisasi agama, yaitu agama hadir berkelabat dalam kecepatan yang melesat ke segala arah. ${ }^{11}$

Ke-eksisan iman Kristen yang tadinya dapat diberitakan secara langsung digerejagereja telah tergantikan dengan keesisan iman Kristen didalam dunia maya. Apalagi saat ini kita hidup digentayangi oleh pandemic Covid-19. Aktifitas persekutuan lebih ditekankan di media masa. Adalah sebuah keuntungan yaitu ke-eksisan firman Tuhan menjadi sebuah keeksisan yang global, sehingga banyak orang yang dapat mendengarkan firman Tuhan.

Persekutuan atau ibadah hanya dijadikan formalitas saja, tidak menghormati makna persekutuan, ibadah yang monoton, tidak serius saat ibadah, bisa saja kita makan sambil

\footnotetext{
${ }^{10}$ John Stoot, The Living Church (Jakarta : BPK. Gunung Mulia, 2008) , 79

${ }^{11}$ Mahyuddin, Masyarakat Dan Gejala Problematika Sosial (Sulawesi Selatan: IAIN Prepare Nusantara, 2020) 166
} 
ibadah, dan yang paling di temukan ialah persekutuan dijadikan keeksisan bagi dunia maya dengan mengambil foto saat ibadah lalu diupload dimedia sosial. Hal inilah yang menjadi sebuah lompatan iman yaitu ke-eksisan iman Kristen digantikan dengan keeksisan pribadi supaya dapat dipuji oleh orang lain dan dilihat bahwa telah hidup dalam persekutuan yang erat dengan Tuhan.

\section{Kesimpulan:}

Pengaruh Teknologi sebenarnya tidaklah menjadi momok yang menakutkan bagi kemajuan iman Kristen. Keesisan firman Tuhan dapat dipertahankan dengan hidup beriman, hidup kudus hidup berkorban bahkan hidup dalam persekutuan dengan Tuhan. Teknologi dan iman Kristen dapat menjadi "sahabat yang karib". Teknologi banyak membantu manusia untuk menjalankan setiap aktifitasnya. Di era post truth tidak menutup keeksisan iman Kristen. Orang Kristen dapat selalu menjadi berkat bagi sesama. Bagaimana kehidupan orang percaya menghidupi ke-4 tiang rohani YPPIB tergantung sejauh mana relasi kita dengan Tuhan dan kebijaksanaan kita menggunakan teknologi. Iman Kristen juga dapat menjadi pewartaan iman Kristen yang mengalahkan tantangan teknologi. Lompatan iman dapat dilalui dengan menggunakan teknologi dengan bijaksana. 


\section{DAFTAR PUSTAKA}

Alimi Moh Yasir, Mediatisasi Agama Post-Truth dan Ketahanan Nasional, 2016, Yogyakarta: LKIs

Dyck, Anni, Tantangan dan Kebutuhan Remaja, 1982, Batu-Malang: YPPII

Faiza , Arum, Sabila J Firda, dkk, Arus Metamorfosa Milenial

Hadiwijono, Harun, Iman Kristen, Jakarta :BPK Gunung Mulia

Hutapea Jakop, Etika Lingkungan, 2019, Malang: UMM

Mahyuddin, Masyarakat Dan Gejala Problematika Sosial, 2020, Sulawesi Selatan: IAIN Prepare Nusantara

Mills, Dag Heward , Bagaimana Menjadi Orang Kristen Yang Kuat, 2015, Parchment House

Nuhamara, Daniel, PAK Remaja, 2008, Bandung: Jurnal Info Media

Sitompul , Einar M., Gereja Menyikapi Perubahan, 2004, Jakarta: BPK. Gunung Mulia

Stoot John, The Living Church, 2008, Jakarta : BPK. Gunung Mulia

Zein, Mohamad Fadhilah, Panduan Menggunakan Media Sosial Untuk Generasi Emas Milenial 